\title{
Homecoming of Brachiaria: Improved Hybrids Prove Useful for African Animal Agriculture
}

\author{
B. L. Maass, C. A. O. Midega, M. Mutimura, V. B. Rahetlah, P. Salgado, J. M. \\ Kabirizi, Z. R. Khan, S. R. Ghimire \& I. M. Rao
}

To cite this article: B. L. Maass, C. A. O. Midega, M. Mutimura, V. B. Rahetlah, P. Salgado, J. M. Kabirizi, Z. R. Khan, S. R. Ghimire \& I. M. Rao (2015) Homecoming of Brachiaria: Improved Hybrids Prove Useful for African Animal Agriculture, East African Agricultural and Forestry Journal, 81:1, 71-78

To link to this article: http://dx.doi.org/10.1080/00128325.2015.1041263

册 Published online: 12 Sep 2015.

Submit your article to this journal ๘

Џ Article views: 424

Q View related articles $₫$

View Crossmark data $\nearrow$ 


\title{
Homecoming of Brachiaria: Improved Hybrids Prove Useful for African Animal Agriculture
}

\author{
B. L. Maass ${ }^{\text {a }}$, C. A. O. Midega ${ }^{\text {b }}$, M. Mutimura ${ }^{\text {, }}$, V. B. Rahetlah ${ }^{\text {d, }}$ P. Salgado ${ }^{\text {e, J. J. Kabirizif }}$, \\ Z. R. Khan ${ }^{\text {b }}$, S. R. Ghimire ${ }^{\mathrm{g}}$ and I. M. Rao ${ }^{\mathrm{h}}$
}

${ }^{a}$ International Center for Tropical Agriculture (CIAT), PO Box 823-00621, Nairobi, Kenya; ${ }^{b}$ African Insect

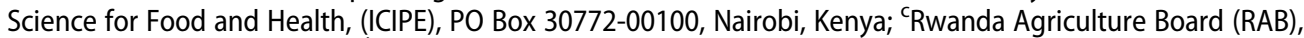
PO Box 5016, Kigali, Rwanda; ${ }^{d}$ Centre de Développement Rural et de Recherche Appliquée, BP 198, Antsirabe 110, Madagascar; ${ }^{e}$ Mediterranean and Tropical Livestock Systems, CIRAD, UMR SELMET, BP 319, Antsirabe

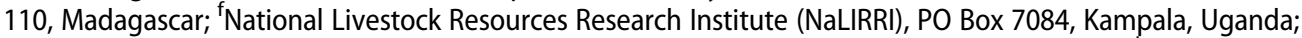

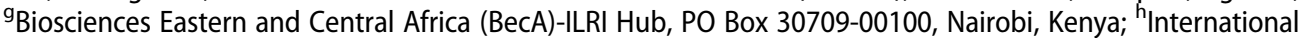
Center for Tropical Agriculture (CIAT), AA 6713, Cali, Colombia

\begin{abstract}
Species of the genus Brachiaria originate primarily from Africa, where they are constituents of natural grasslands. Due to their adaptation to acidic, low-fertility soils, millions of hectares of Brachiaria species have been sown as improved pastures in South and Central America, especially B. brizantha Cv. Marandu and $B$. decumbens cv. Basilisk. Due to $B$. decumbens' susceptibility to spittlebug insect pests in the Americas, CIAT in Colombia and EMBRAPA in Brazil initiated breeding programmes in the 1980s. First cultivars released from CIAT's breeding programme - cvs. Mulato and Mulato-II - have also been investigated in African countries. They have been examined for integration in conservation agriculture systems (Madagascar), for drought and acidic soil tolerance (Rwanda) and for intercropping forages in dairy systems (Uganda, Madagascar), among others. Seed sales to African countries suggest that an area of at least 1,000 ha has been sown so far. The largest adoption of cv. Mulato-II is currently happening in eastern Africa, where it is used by over 20,000 farmers as a trap plant in the push-pull system for control of maize stem borers and parasitic Striga weed. Cv. Mulato-II's particular advantage is its relatively high crude protein content due to greater leafiness and thinner stems than those of traditional Napier grass, resulting in higher nutritive quality. Yet new pest challenges have emerged, requiring further research attention. Diverse hybrids are in the pipeline for release, among them those that are suitable for cut-and-carry systems which are prevalent in eastern Africa. This paper reviews research, development and incipient adoption of new Brachiaria hybrids in African countries.
\end{abstract}

\section{KEYWORDS}

Conservation agriculture; cv. Mulato-ll; East Africa; forage adoption; push-pull system

CONTACT B. L. Maass@BLMaass2015@gmail.com

We gratefully acknowledge the unreserved sharing of information and personal communications (in alphabetical order) by Dr O. Husson, CIRAD, France; R. Jones, Jinja, Uganda; Dr J.M. Lenné, UK; Professor H.M.M. Maraite, UCL, Belgium; Dr. J.W. Miles, CIAT, Colombia; Dr D.M.G. Njarui, KARI, Kenya; Dr M. Peters, CIAT, Colombia; and E. Stern, Tropical Seeds, USA. 


\section{Introduction}

Species of the genus Brachiaria originate primarily from eastern, central and southern Africa, where they are natural constituents of grasslands (Boonman, 1993). The largest impact of Brachiaria in agriculture, though, is in the Americas, especially in Brazil. Due to their adaptation to acidic, low-fertility soils, an estimated 99 million hectares of Brachiaria species have been sown as improved pastures in Brazil alone (Jank et al., 2014). This refers especially to B. brizantha cv. Marandu and B. decumbens cv. Basilisk. Despite Africa being their centre of origin and diversity, Brachiaria species had not been selected for pasture improvement in eastern Africa when grassland research was most active in the 1960s and 1970s (Boonman, 1993). The then available commercial cultivars of B. brizantha, $B$. decumbens, B. ruziziensis and B. humidicola were evaluated in small-plot agronomic trials in western and central Africa in the 1990s (Ndikumana and de Leeuw, 1996). However, none of them appears to have found its way into commercial agriculture at a significant scale in any African country (Boonman, 1993). Only Congo Signal grass (B. ruziziensis, $\mathrm{K} 832^{1}$ ) has been used as a cultivated grass in some areas of the Congo (DRC, formerly also Zaïre), Uganda and Kenya according to Boonman's (1993) review. This nutritious and persistent grass has been in commercial seed multiplication since 1960 .

\section{Brachiaria improvement in the Americas}

Due to the susceptibility to spittlebug insect pests of $B$. decumbens in the Americas, CIAT in Colombia and the Empresa Brasileira de Pesquisa Agropecuária (EMBRAPA) in Brazil initiated breeding programmes in the late 1980s (Miles et al., 2004). Accessing useful resistance genes for cross-breeding was a particular challenge due to the apomictic nature of the grass (i.e. reproducing asexually by seed). This was only made possible by applying modern biotechnological tools then available (Miles et al., 2004), such as embryo rescue and marker-assisted selection. The first inter-specific hybrids from CIAT's Brachiaria breeding programme (cvs. Mulato and Mulato-II) were released in the Americas in the early and mid-2000s by Grupo Papalotla (Table 1). Since 2012, cv. Cayman - as a plant with higher water-logging tolerance - has been made commercially available by Grupo Papalotla (Pizarro, 2013), and the new, relatively taller cv. Cobra, which is more suitable for cut-and-carry systems, will soon be available on the market.

These interspecific hybrids originate from crosses between three Brachiaria species (B. ruziziensis $\times B$. decumbens $\times$ B. brizantha) and subsequent screening conducted by CIAT's Tropical Forages Program in Colombia (Argel et al., 2007). Being apomictic hybrids, these cultivars are true-breeding and will not segregate from one generation to the next.

\section{Commercialization of hybrid Brachiaria}

In 2000, the Mexican seed company Grupo Papalotla/Tropical Seeds entered into agreement with CIAT for 10 years for obtaining rights to commercialize CIAT hybrid

${ }^{1}$ Introduced as CPI 26964; see: http://www2.dpi.qld.gov.au/extra/asp/AusPGRIS/Scripts/Display_Accession.asp? theAccession=AusTRCF26964. 
Table 1. Commercially available hybrid Brachiaria cultivars.

\begin{tabular}{|c|c|c|c|c|}
\hline Cultivar & CIAT ID & Special characteristics & $\begin{array}{l}\text { Country, year of variety } \\
\text { protection (first } \\
\text { release) }\end{array}$ & Reference \\
\hline cv. Mulato & $\begin{array}{l}\text { CIAT } \\
36061\end{array}$ & $\begin{array}{l}\text { Spittlebug-resistant, high forage } \\
\text { yield and nutritive quality, poor } \\
\text { seed fill }\end{array}$ & Mexico, 2004 (2001) & $\begin{array}{l}\text { Argel et al., 2007; } \\
\text { Miles et al., } 2004\end{array}$ \\
\hline cv. Mulato-II & $\begin{array}{l}\text { CIAT } \\
36087\end{array}$ & $\begin{array}{l}\text { Spittlebug-resistant, high forage } \\
\text { yield and nutritive quality, good } \\
\text { seed yield }\end{array}$ & Mexico, 2007 (2005) & Argel et al., 2007 \\
\hline cv. Cayman & $\begin{array}{l}\text { BR02/ } \\
1752\end{array}$ & $\begin{array}{l}\text { Higher tolerance to water logging } \\
\text { than other hybrids }\end{array}$ & Mexico, 2013 (2012) & Pizarro, 2013 \\
\hline (cv. Cobra) & $\begin{array}{l}\text { BR02/ } \\
1794\end{array}$ & $\begin{array}{l}\text { Relatively taller than other hybrids, } \\
\text { suitable for cut-and-carry }\end{array}$ & Mexico, 2013 & $\begin{array}{l}\text { Pers. comms. E. Stern, M. Peters } \\
- \text { cv. name not yet official }\end{array}$ \\
\hline
\end{tabular}

Brachiaria cultivars by receiving the first-generation of hybrids bred during that period for further evaluation and determination of their commercial potential. Papalotla is paying royalties for protected and commercialized cultivars during the protection period (E. Stern, pers. comm.). After expiry of protection 15 years from the first sale, according to the International Union for the Protection of New Varieties of Plants (UPOV), cultivars will pass into the public domain and no other right may prevent free use. Global variety protection for the released cultivars has been obtained in Mexico (Table 1). While Grupo Papalotla/Tropical Seeds has been marketing the seeds directly in the Americas, so far the Australian company Heritage Seeds has been responsible for countries in Oceania, Asia and Africa. Commercial seed production of the hybrids at low latitude in the tropics has been a major challenge. Therefore, Papalotla transferred seed production of $\mathrm{cv}$. Mulato-II to sites of higher latitude $\left(\geq 15^{\circ} \mathrm{N}\right)$ in Mexico and Thailand, from where most exports have been realized (Hare et al., 2013). This paper reviews research, development and incipient uptake of new hybrid Brachiaria cultivars in Africa to document the existing knowledge on their current uses.

\section{Hybrid Brachiaria in Africa}

The first cultivars released from CIAT's breeding programme, cv. Mulato and cv. Mulato-II, have likewise been researched and distributed in Africa. Seed sales (2001-2013) by Grupo Papalotla/Tropical Seeds to African countries (M. Peters, pers. comm.) suggest that an area of at least 1,000 ha has been sown to hybrid Brachiaria hitherto. The new hybrid Brachiaria cultivars have been distributed since 2001 to Eritrea, Ethiopia, Nigeria, DR Congo, Uganda, Rwanda, Burundi, Kenya, Tanzania, Malawi, South Africa and Madagascar according to combined information from seed sales and published research. While the largest share of known commercial seed sales of hybrid Brachiaria cultivars went to Kenya, this only reflects the fact that a big project is being conducted from Kenya $\left(\mathrm{ADOPT}^{2}\right)$, from where the seed is further distributed to participants in Ethiopia and Tanzania. Key findings from both on-station and on-farm research and development, emphasizing agro-ecological adaptation of the plants and their acceptability for farmers, are described below.

\footnotetext{
${ }^{2}$ ADOPT refers to the project 'Adaptation and Dissemination of the 'Push-Pull' Technology to Climate Change'; see http:// push-pull.net/adaptation/vision.
} 


\section{Small-scale agronomic and participatory evaluation}

\section{Rwanda}

During participatory research with farmers on sites with low rainfall and acidic soils in 2007, among various Brachiaria commercial cultivars, released hybrids and advanced lines, cv. Mulato-II was preferred because of producing green forage year round without any fertilizer input, high above-ground biomass production, palatability, drought tolerance, quick regrowth, persistence, being a perennial and easy for cut-andcarry (Mutimura and Everson, 2012). Therefore, cv. Mulato-II is considered an excellent alternative to traditional Napier grass (Pennisetum purpureum) predominantly used in zero-grazed dairy systems of the region. Napier grass, though, has been widely suffering from Napier stunt disease (caused by Phytoplasma) and smut that both decrease severely herbage production and, thus, put dairy-dependent livelihoods at risk (Khan et al., 2014a). More than 150 individual farmers and over four farmer cooperatives are now using cv. Mulato-II as erosion control on contour bunds, livestock forage and hay-making for income generation. Currently, $>50$ ha are planted with cvs. Mulato-II, Marandu and Basilisk to multiply planting material to satisfy the high demand in the country (Pizarro et al., 2013).

\section{Kenya}

While the Kenya Agricultural Research Institute (KARI) set up small-plot agronomic experiments in several KARI research stations across the country in 2011 to compare the performance of $\mathrm{cv}$. Mulato-II with that of available local grasses and to assess its agro-ecological adaptation (D. Njarui, pers. comm.), currently various Brachiaria cultivars are tested, including hybrids, within the new project 'Climate-smart Brachiaria grasses for improved livestock production in East Africa' (see below). At KARI-Kiboko Research Station, cv. Mulato-II was found superior to native range grasses such as buffel (Cenchrus ciliaris) and horsetail grass (Chloris roxburghiana) in both primary dry matter production and subsequent regrowth (Machogu, 2013). It also had higher nutritive quality, especially in terms of high DM digestibility (65\%) assessed in 12-week-old plants, whereas crude protein content (13.3\%) was similar to that of the other grasses. While this trial was conducted with irrigation until 16 weeks after sowing, cv. Mulato-II in another rain-fed trial at Kiboko was heavily infested by red spider mite and both biomass production and plant survival were affected by drought.

\section{Eritrea}

Wolfe et al. (2008) evaluated cv. Mulato at two agricultural research stations in Eritrea, Halhale in the Central Highlands and Shambuko in the Western Lowlands, from 2006 to 2007 and found it was among the most promising grasses in Halhale.

\section{Eastern Democratic Republic of the Congo (DRC)}

Both cv. Mulato and Mulato-II were introduced for assessing agro-ecological adaptation in Sud-Kivu province. Small plots for agronomic evaluation were established at the INERA (Institut National pour l'Etude et la Recherche Agronomiques) Research Station in Mulungu and on farmers' fields in Kabare and Walungu 'groupements'. Cv. Mulato was also evaluated when planted on contour bunds for erosion control within CIALCA 
(Consortium for Improving Agriculture-based Livelihoods in Central Africa) (B.L. Maass, unpublished). Unfortunately, the plants became so severely diseased that evaluation was disrupted and plots abandoned. Not only symptoms of fungal diseases (e.g. rust - probably caused by Uromyces setariae-italicae Yosh - and anthracnose) were found, but also of mites (H. Maraite, pers. comm.). J. Lenné (pers. comm.) explained this undue susceptibility of hybrid Brachiaria as a re-encounter phenomenon induced by returning plants (hosts) selected under completely distinct biotic challenges back to the species' centres of origin and, consequently, centres of diversity also of its diseases and pests.

\section{Madagascar}

The Centre for Rural Development and Applied Research (FIFAMANOR) and the French Centre de Coopération Internationale en Recherche Agronomique pour le Développement (CIRAD) conducted medium-sized plot agronomic experiments to compare the performance of cv. Mulato as compared to other Brachiaria species (B. brizantha, B. decumbens cv. Basilisk, B. humidicola and B. ruzizensis) (P. Salgado, unpublished). Herbage production of cv. Mulato, local B. brizantha and cv. Basilisk was around $20 \mathrm{t} \mathrm{DM/ha/year} \mathrm{and} \mathrm{signifi-}$ cantly higher than that of the other species, while the nutritive value (net energy for lactation) was similar. Rahetlah et al. (2012) demonstrated cv. Mulato's superior herbage production and nutritive value over grass alone when combined with forage groundnut (Arachis pintoi).

\section{Systems integration}

\section{Dairy production systems in Uganda}

Cv. Mulato was introduced as an alternative to Napier grass, the predominant forage for dairy cattle in zero-grazing systems (Kabirizi et al., 2013). After initial on-station and further participatory on-farm evaluation in Masaka district, incipient uptake of cv. Mulato took place (Mugerwa et al., 2012). Demand for cv. Mulato has been increasing since (Kabirizi et al., 2013). Mainly in smallholder dairy systems, cv. Mulato is being used for cut-and-carry, together with legumes like Clitoria ternatea or Centrosema molle (Kabirizi et al., 2013). Cv. Mulato, along with other grasses like B. brizantha cv. Toledo, is now being promoted by non-governmental organizations (NGOs) such as 'Send a Cow' (Kato, 2011). It is recommended to feed drought-tolerant cv. Mulato with a forage legume during the dry season, when Napier grass mono-crops are disadvantaged due to drought, Napier stunt disease and/or poor agronomic practices (Kabirizi et al., 2013). As no seed is available commercially, farmers, even with only small plots, sell vegetative planting material (splits) (B.L. Maass, unpublished). This, hence, creates small-scale agro-business opportunities, especially for women. In the more sub-humid areas around Jinja, cv. Mulato also appears to be an ideal solution for grazing of calves due to its relatively high nutritive quality (R. Jones, pers. comm.).

\section{The push-pull-system in Kenya, Tanzania and Ethiopia}

The largest uptake of hybrid Brachiaria cv. Mulato-II is currently taking place in eastern Africa, where the grass is used as a trap plant in the push-pull system that helps control maize stem borers and the parasitic weed, Striga hermonthica (Khan et al., 2014b). The push-pull-system has been developed and promoted by the International Centre of Insect Physiology and Ecology (icipe) (Khan et al., 2014b). This smart technology 
successfully harnesses agro-biodiversity for improving productivity of cereal crops while providing fodder for livestock. Initially, its components included Napier grass and Silverleaf desmodium (Desmodium uncinatum). Yet, on the systems' limit to semi-arid lands (500-700 mm rainfall p.a.), cv. Mulato-II has been identified as a new trap crop together with Greenleaf desmodium (D. intortum) as the intercrop; both are currently being disseminated. These two components are more drought-tolerant than the traditional ones. In addition, cv. Mulato-II seems to be resistant to Napier stunt disease (Z.R. Khan, unpublished) that devastates Napier grass in the region. Over 20,000 smallholder farmers benefiting from the ADOPT project in Kenya, Uganda, Tanzania, Nigeria and Ethiopia have already planted cv. Mulato-II (C. Midega, unpublished). Farmers in Kenya indicated that their dairy goat milk production has doubled due to the availability of the improved grass and Greenleaf desmodium (B.L. Maass, unpublished). They prefer cv. Mulato-II over Napier grass for several reasons: it is drought-tolerant, highly palatable and nutritious for livestock, easier to handle as cut-and-carry and for making hay to be used during the dry season. As the push-pull-system has been developed to control maize stem borer, little attention has been paid thus far to the possible importance of livestock production improvements for the uptake and further spread of the technology.

\section{Conservation agriculture and dairy systems in Madagascar}

In Madagascar, cv. Mulato has been tested since 2008 for soil structure improvement, high biomass production and carbon accumulation in the soil by its root system as a first step for direct seeding on compacted soils. However, the conservation agriculture system did not spread as initially expected as it requires herbicides for grass control, which are not easily accessible in Madagascar (O. Husson, pers. comm.). On the other hand, in dairy production systems in the highlands, specifically in the Vakinankaratra region, almost 20 ha were planted with cv. Mulato in 2011 (V.B. Rahetlah, unpublished). Owing to its better palatability and higher biomass yield as compared to other Brachiaria spp., cv. Mulato has been rapidly adopted by small-scale dairy farmers. It is mainly grown for green forage production under cut-and-carry systems during the warm and rainy season extending from November to April.

\section{Research and development of new hybrid Brachiaria for Africa}

Despite all the enthusiasm and demand in the region, cv. Mulato-II seed is not yet available on the African market, except for experimental purposes. Therefore, Grupo Papalotla/ Tropical Seeds has requested varietal release from Kenyan authorities, possibly being granted later in 2014. A new research project led by the Biosciences Eastern and Central Africa (BecA)-ILRI Hub that, among other outputs, focuses on integrating improved Brachiaria grasses into smallholder mixed crop-livestock systems, while considering climate-relevant effects on the environment (Djikeng et al., 2014), will most likely push further the adoption of hybrid Brachiaria in the region.

\section{Outlook}

Apparently, hybrid Brachiaria has a role to play in improving African agriculture. However, new pest and disease challenges have emerged that require further research 
attention. On the other hand, an array of diverse hybrids is still in the pipeline for release (Pizarro et al., 2013; E. Stern, pers. comm.); some of these new materials may better address the specific biotic and abiotic challenges identified as well as the requirements for particular production systems in African locations. In order to maximize benefits for smallholder farmers and deploy the new hybrid Brachiaria cultivars effectively, the following research needs and opportunities have been identified:

- Researchable knowledge gaps (e.g. effects on livestock production in mixed crop-livestock systems; agronomy of system-integration; assessing the socio-ecological niche considering gender and economics, and adoptability by smallholder farmers)

- Upcoming research needs (e.g. dealing with biotic challenges like red spider mite, sorghum shoot fly, fungal diseases; seed production on the continent)

- Research and development opportunities (e.g. testing advanced hybrids under biotic and abiotic stress as well as in representative African production systems; fitting the right cultivars into different production systems and further develop their agronomy)

Brachiaria, so far neglected grasses in their continent of origin, have not only returned home in the form of improved hybrids, but they have been very welcome by African farmers.

\section{References}

Argel, P.J., Miles, J.W., Guiot García, J.D., Cuadrado Capella, H. and Lascano, C.E. (2007). Cultivar Mulato II (Brachiaria hybrid CIAT 36087): A high-quality forage grass, resistant to spittlebugs and adapted to well-drained, acid tropical soils. International Center for Tropical Agriculture (CIAT), Cali, Colombia.

Boonman, J.G. (1993). East Africa's grasses and fodders: Their ecology and husbandry. Kluwer Academic Publishers, Dordrecht.

Djikeng, A., Rao, I.M., Njarui, D., Mutimura, M., Caradus, J., Ghimire, S.R., Johnson, L., Cardoso, J.A., Ahonsi, M. and Kelemu, S. (2014). Climate-smart Brachiaria grasses for improving livestock production in East Africa. Tropical Grasslands-Forrajes Tropicales 2(1): 38-39.

Hare, M.D., Phengphet, S., Songsiri, T., Sutin, N., Vernon, E.S. and Stern, E. (2013). Impact of tropical forage seed development in villages in Thailand and Laos: Research to village farmer production to seed export. Tropical Grasslands- Forrajes Tropicales 1(2): 207-211.

Jank, L., Barrios, S.C., Valle do, C.B., Simeão, R.M. and Alves, G.F. (2014). The value of improved pastures to Brazilian beef production. Crop and Pasture Science 65(11): 1132-1137.

Kabirizi, J., Zziwa, E., Mugerwa, S. and Namagembe, A. (2013). Dry season forages for improving dairy cattle production in smallholder dairy systems. Tropical Grasslands-Forrajes Tropicales 1 (2): 212-214.

Kato, J. (2011). Start preparing for the dry season. New Vision, Uganda. http://www.newvision.co. ug/D/9/756/756237 (last accessed 24 March 2014).

Khan, Z.R., Midega, C.A.O., Nyang'au, I.M., Murage, A., Pittchar, J., Agutu, L.O. and Pickett, J.A. (2014a). Farmers' knowledge and perceptions of the stunting disease of Napier grass in Western Kenya. Plant Pathology 63: 1426-1435.

Khan, Z.R., Midega, C.A., Pittchar, J.O., Murage, A.W., Birkett, M.A., Bruce, T.J. and Pickett, J.A. (2014b). Achieving food security for one million sub-Saharan African poor through push-pull innovation by 2020. Philosophical Transactions of the Royal Society B 369(1639): 20120284.

Machogu, C. (2013). A comparative study of the productivity of Brachiaria hybrid cv. Mulato II and native pasture species in semi-arid rangelands of Kenya. MSc thesis, University of Nairobi, Kenya. http://erepository.uonbi.ac.ke/handle/11295/56273 (last accessed 24 March 2014). 
Miles, J.W., Valle, C.B. do, Rao, I.M. and Euclides, V.P.B. (2004). Brachiariagrasses. In: Moser, L.E., Burson, B.L. and Sollenberger, L.E. (eds), Warm-Season (C4) Grasses. American Society of Agronomy, Crop Science Society of America, and Soil Science Society of America, Madison, WI, pp. 745-783.

Mugerwa, S., Kabirizi, J.M., Njarui, M.D. and Mpairwe, D. (2012). Utilization of introduced forages by smallholder dairy farmers in Uganda. International Journal of Biosciences 2: 36-45.

Mutimura, M. and Everson, T. (2012). On-farm evaluation of improved Brachiaria grasses in low rainfall and aluminium toxicity prone areas of Rwanda. International Journal of Biodiversity Conservation 4(3): 137-154.

Ndikumana, J. and de Leeuw, P.N. (1996). Regional experience with Brachiaria: Sub-Saharan Africa. In: Miles, J.W., Maass, B.L. and Valle, C.B. do (eds), Brachiaria: Biology, Agronomy, and Improvement. CIAT and EMBRAPA/CNPGC, Cali (Colombia), pp. 247-257.

Pizarro, E.A. (2013). Un nuevo híbrido para el mundo tropical: Brachiaria híbrida cv. CIAT BR02/ 1752 "Cayman". Pasturas de América, June 2013. http://www.pasturasdeamerica.com/articulosinteres/notas-tecnicas/brachiaria-hibrida-cayman/ (last accessed 22 August 2014).

Pizarro, E.A., Hare, M.D., Mutimura, M. and Changjun, B. (2013). Brachiaria hybrids: potential, forage use and seed yield. Tropical Grasslands-Forrajes Tropicales 1(1): 31-35.

Rahetlah, V.B., Randrianaivoarivony, J.M., Andrianarisoa, B., Razafimpamoa, L.H. and Ramalanjaona, V.L. (2012). Yield and quality of Brachiaria sp. cv Mulato-forage perennial peanut (Arachis pintoi) mixture in the highlands of Madagascar. Livestock Research for Rural Development. 24(10), Article \#171. http://www.lrrd.org/lrrd24/10/rahe24171.htm (last accessed 20 August 2014).

Wolfe, E.C., Tesfai, T., Cook, B., Tesfay, E. and Bowman, A. (2008). Forages for agricultural production and catchment protection in Eritrea. In: Unkovich, M. (ed.), Proceedings of the 14th Australian Agronomy Conference on Global Issues, Paddock Action, Adelaide, South Australia, Australian Society of Agronomy. http://www.survey.regional.org.au/au/asa/2008/ concurrent/agronomy-abroad/5644_wolfeec.htm (last accessed 30 August 2014). 